level of another hormone disruptor, bisphenol A (BPA), in the environment. Opponents of such restrictions claim that their advocates are excessive, hysterical scaremongers. Langston's book is an efficient antidote to such accusations. Her tone is measured and calm, but the story she tells is very upsetting. At its center is DES, a synthetic estrogen first produced in the laboratory in 1938 and rapidly proposed as a treatment of menopausal symptoms, in spite of early reports of potential carcinogenic activity. In the 1940 s some doctors also started to prescribe DES for troubles associated with pregnancy. They argued that this substance reduced the risk of miscarriage and helped to produce healthier and stronger babies, without bothering to investigate the veracity of this claim or DES's possible harms.

Langston's study carefully documents the way the industry billed and sold DES as a miracle substance. Publicity for DES hailed it as a substance that "possesses the same activity as natural estrogens." The argument that DES had the same effect as a natural substance was aimed at disarming critics, while the argument that it was "similar [to estrogen] but much cheaper" was a powerful sales pitch. In the 1940s, 1950s, and 1960s, DES was used to treat a variety of conditions in women as well as one male pathology: advanced prostate cancer. The latter use was not contested. When the patient's life was at stake, it was considered acceptable to use a drug that produced harmful side effects. This was emphatically not the case, however, for the main uses of DES by women. This substance was employed to treat non-pathological conditions such as menopause, lactation, and pregnancy. The use of DES by pregnant women was especially disastrous. In 1971, doctors found out that some of the daughters of women who took DES when pregnant developed a rare cancer, clear cell adenocarcinoma of the vagina. Others suffered from a malformation of the reproductive tract. These findings and the self-organization of "DES daughters" played an important role in the development of the women's health movement in the United States.

At the same time, farmers used DES to "feminize" roosters and increase the market value of old hens by making their meat more tender. They also fed it to calves to increase their meat production. In the 1970 s scientists accumulated an impressive body of evidence regarding the potential harms of DES in food and called for a ban on its veterinary uses. Pharmaceutical companies strongly resisted this measure, while the Food and Drug Administration (FDA) was slow to implement restrictions on feeding DES to animals. Today animals are no longer given DES, but legislators are still reluctant to restrict the use of BPA, a molecule strongly suspected of affecting the sexual development of fetuses, hampering the self-repair mechanisms of the body, and disturbing fragile ecosystems.

This behavior is not exceptional. The regulatory history of other health hazards-from mercury and asbestos to tobacco and DES - shows that public authorities are very slow to act, even when faced with highly persuasive evidence. Their usual attitude is that one should assume that an investigated substance is innocent until found guilty. This may be an appropriate attitude when dealing with humans accused of crimes, but it is more problematic when managing toxic substances. The call for more evidence and more research is frequently a strategy that keeps profitable chemicals on the market as long as possible. Langston advocates a different regulatory approach: more humble, more experimental, and more willing to acknowledge that people make mistakes.

Langston's final recommendations are imminently reasonable: keep an open mind, and when several possibilities are open, always choose the one that, in the present state of knowledge, is less dangerous. The present state of knowledge, she explains, is a contested field, but not an infinitely contested one. This book provides numerous examples of the abandonment of the precautionary principle and truly distressing lapses of vigilance on the part of regulatory bodies. My only minor criticism is that Langston's study might have benefited from a better distinction between truly disastrous consequences of environmental pollutants, such as the production of cancers, and less drastic potential effects, such as a possible deterioration of the quality of women's milk, which may deprive their children of the benefits of breastfeeding. This criticism excepted, Langston makes a highly persuasive case for a wise use of the precautionary principle to protect ourselves, our children, and the life around us.

ILANA LÖWY

École des Hautes Études en Sciences Sociales, Paris $V$

\section{CARIBBEAN AND LATIN AMERICA}

Gillian McGillivray. Blazing Cane: Sugar Communities, Class, and State Formation in Cuba, 1868-1959. (American Encounters/Global Interactions.) Durham, N.C.: Duke University Press. 2009. Pp. xxvi, 386. Cloth $\$ 89.95$, paper $\$ 24.95$.

Gillian McGillivray provides an innovative history of Cuba through the production of sugar, the island's principal export and source of labor since the late colonial period. She pursues several broader goals: to weigh the historical impact of the United States on republican Cuba (1902-1959); to identify the practicalities of $\mathrm{Cu}-$ ba's republican state formation; and to highlight the island's commonalities with the rest of the Americasrather than its exceptionalism.

As its title indicates, the book gives agency to sugar producers. Indeed, until 1959 cane burning was a potent way for Cuba's cane farmers and workers as well as Cuban revolutionaries to gain political and economic power. It allowed producers to have greater control of the harvest season, to improve their working conditions, and to protest political repression. In a broader way, cane burning also represented revolutionaries' most meaningful attack on colonialism and imperialism; ultimately it contributed to the nationalization of 
sugar mills. From 1959 to 1961, it continued to be used by "counterrevolutionaries" to protest Fidel Castro's reforms and nationalization.

In order to examine how sugar farmers (colonos) and workers contributed to the Cuban governments' move from exclusive to inclusive politics and back again, McGillivray closely studies two sugar communitiesTuinucú in southern Santa Clara and Chaparra-Delicias in northern Oriente-tied to national and U.S.-Cuban developments through their owners and administrators and to the Cuban labor movement through their workers. Her comparison between these two communities shows complex differences in organization, management, and class relations; it also reveals new dimensions in the personalities of national politicians who gained power and wealth thanks to U.S. patronage.

Through her multilevel perspective, the author defines three periods in the political development of the sugar cane industry and its labor relations that she characterizes as "compacts" or systems of negotiation among the Cuban state, capitalists, and the popular classes. First, the "colonial compact," from the Spanish colonial period to the first U.S. intervention (18981902), developed in the wake of the Haitian revolution and continental independences from Spain. Cuban planters implicitly agreed to remain in a Spanish colony in exchange for the king's promise to protect the institution of slavery. After attacks from below during the Ten Years' War and the 1886 abolition of slavery, the colonial compact was redesigned: sugar mill owners and cane farmers agreed to colonial rule in exchange for control over workers and the ability to make profits. Next, the "patron's compact" extended from independence under the Platt Amendment in 1902 to 1932. Liberal and Conservative caudillos emerged from the wars for independence and built vast political and business networks including sugar workers, colonos, and Cuban and U.S. mill owners. They kept sugar communities under control through patronage, capitalist welfare (housing, education, health care), and repression. Yet the 1929 crisis and the Depression brought an end to the "patron's compact" so tied to foreign interests. A “populist compact" began in 1933 and continued until 1959, moving from authoritarian populism (1934-1936) through a redistributive phase (1937-1944), Cold War readjustment (1947-1955), and Fulgencio Batista's dictatorship (1955-1959).

This book is grounded in extensive research at the Braga Brothers Collection in Florida and the CubanAmerican Sugar Mills Collection in the provincial archives of Las Tunas. McGillivray masterfully combines these sources with documents from Cuban provincial and national archives, the U.S. National Archives , and the Public Record Office; newspaper articles; interviews by the author and by Cuban historians; and carefully analyzed sources found in the secondary literature.

Over the book's eight chapters, she weaves a history from below, presenting compacts from the perspective of workers, colonos, administrators, and owners (and their families); a more political history of Cuba and its relationship with the United States; and a broader sociopolitical history of Latin America. McGillivray's success, except in a few instances in which the changing relations between colonos and workers remains a bit confused, is impressive given Cuba's complex post-1932 political history.

One of McGillivray's most important contributions is her analysis of Cuba's rural middle class, the colonos "sandwiched between the mill owners and the wage workers" (p. 14). Although mostly white, the colonos were a socially diverse mix of sharecroppers and small and large, often absentee, landowners. The colono middle class formed after the abolition of slavery, when sugar production divided into an agricultural sector that grew and harvested cane and an industrial sector of sugar mills. Colonos played a major role in the negotiation of each compact. They reached the apogee of their influence with the Sugar Coordination Act of 1937 that offered national(ist) protection to Cuban colonos and mill owners and resulted in Cubans owning almost seventy percent of the sugar industry before the 1959 revolution.

This book offers a new understanding of Cuba's sugar politics. It will prove essential to anyone interested in pre-1959 Cuban history or in the relationship of the middle class to state formation in Latin America.

Aline Helg

University of Geneva

Steven Palmer. Launching Global Health: The Caribbean Odyssey of the Rockefeller Foundation. (Conversations in Medicine and Society.) Ann Arbor: University of Michigan Press. 2010. Pp. xi, 301. \$70.00.

In the early twentieth century the Rockefeller Foundation's International Health Board set out to combat widespread hookworm infection and disease in the $\mathrm{Ca}-$ ribbean Basin. While many historians have dismissed this episode as less significant than the Rockefeller Foundation's grander campaigns against yellow fever and malaria, Steven Palmer demonstrates in this superb book that it is a tale well worth telling. The book's broad project, which spans Nicaragua, Guatemala, Costa Rica, Trinidad, British Guiana, and Panama, poses a challenge to any researcher intending to do justice to both local dynamics and regional heterogeneity. Palmer strikes a graceful balance, offering a compelling alternative to top-down analyses of medical imperialism.

The International Health Board envisioned an intensive treatment system that involved the mapping and counting of each dwelling, road, and water reservoir, and called for an examination of every resident for signs of infection. This quintessential example of what Michel Foucault might call biopower, however, underwent translation as soon as it encountered autochthonous methods of combating hookworm. Palmer's close reading of evidence, such as notices sent to patients deemed in need of treatment, support his broader argument about the ways local medical language made incursions 